\title{
International Students' Choice Behavior for Higher Education at Malaysian Private Universities
}

\author{
Siti Falindah Padlee \\ Faculty of Management \& Economics, Universiti Malaysia Terengganu \\ 21030 Kuala Terengganu, Malaysia \\ Tel: 60-9-668-3275 E-mail: siti.padlee@buseco.monash.edu.au \\ Abdul Razak Kamaruddin (Corresponding author) \\ Faculty of Management \& Economics, Universiti Malaysia Terengganu \\ 21030 Kuala Terengganu, Malaysia \\ Tel: 60-9-668-3275 E-mail: abrazak@umt.edu.my \\ Rohaizat Baharun \\ Faculrty of Management \& Human Resource Development, Universiti Teknologi Malaysia \\ Locked Bag 791, 80990 Johor Bahru, Malaysia \\ Tel: 60-7-553-1823 E-mail: m-rohaizat@utm.my
}

\begin{abstract}
The paper is to examine the selection criteria by international students of their higher education at private higher learning institutions in Malaysia. It focuses on factors which private international students considered important in their decision of choosing Malaysia as their educational destination. A questionnaire was designed to include 48 factors for selection of learning destination. Through judgmental sampling the data were solicited from 565 international students using survey instrument. These were analyzed on principal components factor analysis to ascertain factors related to their criteria to study in Malaysia. The results shown that six factors have a strong influence on international students' decision-making process, namely, quality of learning environment, influencers, customer focus, cost, facilities, socialization and location. Further, through MANOVA, it was found that customer focus and facilities are the main factors used by respondents in their choice decisions. These factors should be considered by colleges' managers to develop their marketing strategies in attracting foreign students to enroll at their institutions. It is also important for positioning strategy and strengthening higher learning institution offerings to the foreign market.
\end{abstract}

Keywords: International students, Higher learning, Choice criteria, Malaysia

\section{Introduction}

In most countries, tertiary education industry has experienced a number of significant changes. According to Hemsley-Brown and Oplatka (2006), higher learning institutions (HEIs) are widespread and well-established as a global phenomenon, especially in major English-speaking nations such as the United States (US), United Kingdom (UK), Australia, Canada and New Zealand. In the US for example, HEIs are undergoing substantial change in terms of the way colleges and universities are functioning because of factors such as demographics, globalization, economic restructuring and information technology. These changes have led HEIs in the US to adopt new concepts of educational market and organizational structures. As the competition among them intensifies, they increasingly behave as business entities by adopting more business strategies. In recent years, they have promoted the acceleration of international linkages, branch campuses, single purpose programs and other forms of transnational education and quality of education for the customers.

However, the task for all the activities mentioned, is not always easy, especially to remain competitive in the eye of customers at the global environment. Other factors such as government intervention, international law, different customs procedures, varieties of languages, foreign exchange, different costs, different behaviors, perception, and life styles are challenges for higher learning institutions in trying to provide a quality and sustainable education program. One study undertaken by Paramewaran and Glowacka (1995) found that HEIs need to maintain or develop a distinct image to create a competitive advantage in an increasingly competitive 
market. In a number of countries, governments have been painstakingly stressed the economic benefits resulting from higher education. The education sector is worth hundreds of billions of dollars in today's market, and every week saw a new joint-venture being announced by traditional or new players all over the world, as they jockey for a position in this increasingly global market.

In the Malaysian context, the government in the 1980's recognized that it would be unable to educate more than six percent of its population through its own institutions and began to partner with international institutions to supplement its system of higher education (Lenn, 2000). For the past 50 years, many Malaysians have been sent to English speaking nations to study at chosen HEIs. In recent years, this move has led to the government inviting foreign universities to operate in Malaysia. With this move, the government has made another important decision to turn Malaysia into an educational hub in the region. Both public and private HEIs have to take more responsibilities for the overall products and services offered to customers. Therefore, many HEIs have already adopted some form of business strategies, especially marketing, for strategic activities in their operations.

Education and education marketing is a service industry and this presents a particular set of challenges for practitioners (Ross, Heaney and Cooper, 2007) and in the service industry the main focus is the students-cum-customers. Selecting a HEI is first step the international students undertake in the educational process of higher education. Furthermore, selecting a HEI is a momentous decision that may shape not only the life and success of students' careers but their families as well. In the choice criteria review, the student-cum-customer must decide which HEI to attend while facing the influence by mass media, parents, peers, location, cost, and other variables. This phenomenon has encouraged HEIs to place greater emphasis on international student enrollment. Due to the importance associated with the choice criteria and how it influences the potential student's decision-making process, various initiatives were taken to increase enrollment. In Malaysia recently, international students are considered as a new group of students who go to higher learning institutions in order to enroll in higher education studies outside their own country. A considerable segment of foreign customers of HEIs are currently demanding a kind of education that may be different from the local Malaysian students. In the new environment, HEIs especially private HEIs must therefore identify these "new" (foreign) customers and determine their needs in order to be able to adapt and serve them. This strategy is considered important for the survival of private HEIs towards achieving high students' satisfaction and loyalty. All HEIs in Malaysia realize that international student recruitment is of paramount importance for them as a means of generating income and to be financially able.

Thus, the focus of this study is to examine the behavior of international students in selecting a HEI and the relative credibility placed on them of various selection criteria. This paper also attempts to answer a question: what are the factors that influence international students in choosing Malaysia as the destination for their study? The paper is organized as follows: First, an overview of higher education industries in Malaysia and around the world is discussed. Next, the methodology and results of the study are presented. The paper concludes with key findings, limitations of the study and future research directions.

\section{Literature Review}

Higher education is of obvious importance in supporting national economic objectives of every country in the world and for the development of the indigenous labor forces, including the direct rise of extra-national income. In the US, education is the second largest export market after agriculture and the second largest domestic industry after health care (Abeless 2001). Currently, the US is the leader in the market, for international education, followed by the UK and Australia (Binsardi and Ekwulugo, 2003). In terms of investment, countries such as Australia, Canada, the US and Korea invest, respectively, 1.1, 1.5, 2.5 and 2.7 per cent of their GDP on higher education (Cornuel, 2007). In Malaysia, besides government-funded HEIs, there are quite a number of HEIs from subsidiaries of major conglomerates and some of these HEIs are listed in the Bursa Kuala Lumpur (Kuala Lumpur Stock Exchange) as their roles are understandably entrepreneurial in nature.

For Malaysia perspective, there are four national goals to be realized in the restructuring of private HEIs, i.e., i) to produce the necessary human resources for the country; ii) to export higher education; iii) to stem the flow of higher education students offshore in order to reduce the outflow of Malaysian currency and iv) to enroll 40 per cent of student-age cohort in higher education by the year 2020 in order to realize the aim to make Malaysia an industrialized country (Tan, 2002). By the mid-1990s, there were two major types of private HEIs in Malaysia, the single-discipline colleges and the comprehensive course-delivery colleges. The majority of the private HEIs were developing into the latter category, engaging in comprehensive course-delivery (Noran and Ahmad, 1997). Most private HEIs in Malaysia are located in the Klang Valley, in the state of Selangor which is one of the developed states in Peninsular Malaysia. To date, there are 16 private universities and college universities and 
five branch campuses of reputable foreign universities from Australia and the UK. The policy of liberalization and democratization of education introduced by the Malaysian government through the introduction of the Higher Education Act, has resulted in an increase of international students in Malaysia since 1996. It is proven the international students enrolment in Malaysia, which has increased rapidly from 32 in 1970 to 126,005 in 1999 (Hanapi, Zahiruddin and Mohd Shah, 2003). In 2004 alone, there were about 39,763 international students enrolled in Malaysian private HEIs (Habhajan, 2004).

Most research on factors that influence the decision making of foreign students to pursue higher education in host countries are conducted in developed countries. Maringe and Carter (2007) suggested that most of the studies student overseas decision making is modeled by a combination of pull-push factors. According to Mazzarol and Soutar (2002) there are many factors influencing students to choose international education, such as lack of access to higher education especially in Asia and Africa, a commonality of languages and availability of technology-based programs. For countries such as Australia, France, the UK and USA, quality management in education is a major focus of attention (Lindsay, 1994). In another study done by Mazzarol and Hosie (1996) found that many of the students had been recruited for study in Australia by an education agent mentioned that friends are the most commonly cited source of information about HEIs. The findings from the studies mentioned above, have important implications for strategic international student marketing, recruitment and retention and used as a basis of this study.

As competition increases in the education industry, many HEIs increasingly view students as consumers. As such, HEIs are forced to equip themselves with the necessary marketing intelligence and information that would enable them to face challenges, especially in the international markets. On the students' side, they have a "membership" relationship with the education service. Students considered themselves to be the main decision-makers. In other words, foreign students more demanding for better value for their money and are more selective in choosing an educational institution. While criteria of the choices of study destinations have been widely researched, the results are at best mixed. Major works regarding choices of criteria within the HEIs' environment, likewise shows the multi-dimensional nature of this concept. Thus, the main studies performed within HEIs show the dimensions as illustrated in Table 1. The variety of variables shown creates difficulties while attempting to develop an ideal concept for this study.

\section{Insert Table 1 about here}

As shown in Table 1, among the potential dimensions of choices of criteria are aspects such as accommodation, library, laboratory, cafeterias, students' union. These aspects could be categorized as facilities or infrastructure dimensions. Academic staff elements such as teaching quality, staff qualification, teaching quality, medium of instruction, reputation, and image appear as significant factors in teaching and learning quality. HEIs with large faculty and facilities may attract more students (Tang, Tang and Tang, 2004). Cost factor is also highlighted, which would include tuition fees, costs of living, prices of services, etc. As prices for tuition rise, enrolment rates tend to fall. The fourth factor refers to the environment surrounding students such as campus life, safety, campus design, social life and people surrounding the HEI compounds. Support services such as medical, international schools, part-time jobs, children kindergartens, banks, counseling, financial support, career guidance were also highlighted in these studies. A decision-making process by potential student is often influenced by "significant others" such as friends, parents, counselors, other students, teachers and university admission officers, internet, mass media and sometime the league tables.

Majority of these dimensions are within the domain of HEIs and considered as critical choice criteria by international students. On the other hand, a systematic review of literature done by Hemsley-Brown and Oplatka (2006) on higher education marketing and they divided researches in this area into 11, such as marketing communication, image and reputation, application of marketing models, transactional marketing, relationship marketing, strategic approaches in marketing, extending participation in HEIs, strategic tools of marketing, market segmentation, market positioning, and market planning.

In the study of choice criteria, the vast majority of studies dealt with only one country samples, such as US (DeShields Jr. et al, 2005), Indonesia (Joseph and Joseph 2000), Australia (Soutar and Turner 2002), Taiwan (Chen and Zimitat 2006), Malaysia (Rohaizat 2004), Spain (Navarro et al, 2005) and Turkey (Yamamoto 2006). According to Joseph and Joseph (2000), there is very little of cultural distance if samples from one country were used in the study. As Cubillo, Sanchez and Cervino (2006) point out, this a growing number of international students in search of higher education out side their own country, has increased the need for understanding the behavior of these students from a cross-national perspective. Only a few studies have used international students as their samples, such as Binsardi and Ekwulugo (2003), Hanapi et al (2003) and Mazzarol and Soutar (2002). 
Although very little is written about Malaysian education in the international arena, the number of foreign students choosing Malaysia as their education destination continues to rise annually, thus making this research imperative. In the spirit of the preceding discussion, the researchers have embarked on this researche endeavor.

\section{Methodology and Research Design}

The study focuses on the choice criteria of international students enrolled in private higher learning institutions in Malaysia was conducted at a various locations such as Kuala Lumpur, Shah Alam, Ipoh, Cyberjaya and Melaka. Due to limited access to all private higher learning institutions, judgmental sampling was used with the help of the associations representing Malaysia's HEIs such as NAPIEI (National Association of Private and Independent Educational Institutions) and PKIBM (National Association of Indigenous Private Educational Institutions). The sampling unit comprised of international students from various countries studying in Malaysian private higher educational institutions in various degree programs. A total of 1500 questionnaires were distributed to selected respondents at six private HEIs. The institutions were chosen based on enrollment of international students. However, only 656 foreign students responded to the survey which is $43.7 \%$ response rate. This number was considered satisfactory for statistical analysis and representative of the population strata.

The questionnaire was designed based on focus group meeting and secondary information from numerous studies such as Soutar and Turner (2002), Joseph and Joseph (1998 and 2000), and Leblanc and Nguyen (1999). After the pre-test activity, a final 48 variable item questions were used. The questionnaire is divided into two parts. The first section of the questionnaire asked respondents to rank the different dimensions on a scale of 1 (extremely unimportant) to 6 (extremely important). In the second part, respondents were asked about their profile or background such as country of origin, age, gender and types of studies. These measures were culled from the previous study of Rohaizat (2004).

\section{Discussion of Findings}

The analyzed sample is comprises mainly men ( 65.5 percent). Majority of the respondents (94 percent) comprises students who are below 25 years of age. Students from South-east Asia make up the largest population of the sample (32 percent) and the least are from North America, Europe and Oceania (2 percent). With regard to program enrollment, 376 of the students were enrolled in bachelor or first degree programs (56.4 percent) and only 6.4 percent were enrolled in pre-diploma and diploma level programs.

The respondents were asked to indicate their levels of agreement or disagreement with statements regarding the variables included in the questionnaires. Table 2 shows the most important and the least important items indicated by the students. The summary of means shows that students placed a great deal of importance on all the items of selection. Most of the items have a mean score range of 4 to 3 except for the item "outskirts of the city" with a mean of 2.93. It is indicated that from the ten choice criteria, "entry qualification", "English usage" and "English language" were the most important criteria of choice whereas the item "outskirts of the city" is the least important criteria of choice ranked by the international students.

\section{Insert Table 2 about here}

After determining the mean analysis, a factor analysis was performed. Factor analysis is a data reduction technique that can help determine a smaller number of underlying dimensions of a large set of inter-correlated variables. Factor analysis was used to assess the nomological validity of the choice criteria, while discriminant validity of the choice criteria was examined through the rotated factors scores across all of the identified factors (Joseph and Joseph, 2000).

Table 3 shows the factor loadings identified by each of the samples of international students involved in this study. Factor analysis with varimax rotation was used to determine the underlying dimensions of 48 criteria of choices. All factors with eigenvalues or latent roots of 1.0 or greater are considered significant and reported. Items were removed if factor loadings were less than 0.40 (Hair and Black, 1998). However, in this study, only items with factor loadings of 0.5 and above are taken based on the by Nunnally (1978. Furthermore, alpha value was used to identify the reliability of identified factors. The scale for reliabilities was determined by the non-standardized Cronbach alpha which is reported to be the preferred method and widely used.

The naming of a factor-loading matrix is a highly arbitrary decision of the researcher. In this study, the interpretation of the factor-loading matrix was straightforward. The seven factors are quality learning environment, decision influencers, customer focus, and cost of education, facilities, location and socialization. The first dimension explains 36.7 percent of the variance and the second dimension explains seven percent of the variance. The aspects pertaining to the customer orientation are included in the third component which explains four percent of the variance. The fourth component (cost) explains three percent and the items are tuition fee, 
accommodation fee, exchange rate and availability of funding. The fifth component, facilities, comprised of internet/computer facilities, sports facilities, design of the building and campus and clean and tiny environment, also explain three percent of the variance. The last component is socialization, which include the university location at urban area and availability of part-time job. All the seven factors explain 57 percent of the total variance. Thus, a model with seven factors should be adequate and the analysis can be considered satisfactory since they do not exceed 60 percent of the explained variance recommended in social sciences (Hair, et al., 1998).

A reliability test of the detected underlying scales was performed and the results showed reliabilities of between 0.91 and 0.52 for the six factors, which are considered sufficient (Nunnally, 1978) except for the last factor (location). The alpha coefficients for the factors show that the majority are highly reliable and acceptable, with alpha scores exceeding 0.5 , the threshold recommended by Nunnally (1978) for exploratory research. The results for the factor analysis also show that the Kaiser-Meyer-Olkin (KMO) score is 0.756 and the Bartlett's Test of Sphericity value was significant $($ Chi square $=5675.15, \mathrm{p}<0.05)$. This KMO value shows that the sampling was adequate and therefore acceptable, and the distribution of value is adequate for conducting factor analysis.

\section{Insert Table 3 about here}

Furthermore, to evaluate the importance of decision-making process on choice criteria for various groups, a multiple analysis of variance (MANOVA) technique was employed. According to Sunita, Pentecost and Ofstad (2006) the main advantage of this technique is protection against Type 1 error and ability to reveal differences not shown in separate analysis of variance (ANOVA). On the other hand, Malhotra (1999) states that MANOVA examines group differences across multiple dependent variables simultaneously. Table 5 shows the results of the relationship of the seven factors and students from various regions using the MANOVA test. The results indicate that students from African nations have a strong relationship with factors learning environment, customer focus and location. Meanwhile customer focus appears to be the most important factor for all the nations. These results suggest two findings: first, different students from different nations require different needs and wants, and secondly, international students hope that they are given due importance as customers because they are paying for a higher proportion of the overall cost of their studies.

\section{Insert Table 4 about here}

\section{Conclusion}

To achieve the nation's goal to become the regional education hub, higher educational institutions in Malaysia especially the private institutions must identify what are the criteria used by international students in selecting their study destination. This research highlighted several aspects relating to student's criteria of choice of study destination. First, the study identified five most important factors; qualification of the teaching staff, English usage, English language specialized field and top-notch staff were considered important by international students selection criteria. By identifying the aspects of choice criteria, the HEIs can attract potential international students by delivering the essential criteria required through effective marketing strategies. It makes sense to adopt a marketing policy to suit the specific requirements and culture of prospective students in these countries. Through factor analysis, seven dimensions were revealed in explaining the decision criteria of international students, i.e., learning environment, influencers, customer focus, cost, facilities, socialization and location.

Selecting a higher education institution to study or attend is a momentous decision that may shape the life and success of a student's career and his/her family. According to Joseph and Joseph (1998), the items selected by the international students should be a concern by the HEIs to market positioning strategy and to strengthen their offerings in these areas. Second, the items which are most related to services such as quality education, cost, and facilities provided by the HEIs are the key aspects that determine the decision-making process by the international students and these factors should be addressed by the HEIs. If the HEIs have the ability to help minimize dissatisfaction and increase retention of students is an important marketing strategy to them. On the students' side, they faced stiff competition for admission to their own nations' best HEIs. There are limited spots for undergraduate students in HEIs in their countries because the demand is very high. Studying in foreign countries and foreign HEIs is one of the alternatives. Lastly, students and their parents have to find the good fit between HEIs and the students so that they will ensure the completion of their study.

Finally, the study has accomplished its main objective that we are better informed as to which choice criteria students prefer and perceive to be reliable to consider. In spite of the importance of the results obtained, it is also important to highlight some of the limitations of the study, which further research will endeavor to remedy. The samples are limited to international students at only selected private universities in Malaysia. This could limit the generalization of the research findings. Further research could use a larger range of students with a more 
diversified background and investigating the selection criteria of postgraduate students. Consequently, in future studies, the choice criteria of selecting HEIs should be analyzed from the perspective of the various stakeholder groups such as parents, secondary school students, and employers who interact with the HEIs. In the writers' opinions, it would be necessary to corroborate the results obtained in this study and other studies and expand the results to other elements that make up the current offers by the HEIs all over the world. Another interesting area would be comparative analysis between purchase intention for prospective students at the particular regions and purchase decision by the international students.

\section{References}

Abeless, T. P. (2001). Rethinking the university. The Journal of Future Studies, Strategic Thinking andPolicy, 3(6), 563-568.

Binsardi, A., \& Ekwulugo, F. (2003). International marketing of British education: Research on the students' perception and the UK market penetration. Marketing Intelligence \& Planning, 21(5), 318-327.

Chen, C.H., \& Zimitat, C. (2006). Understanding Taiwanese students' decision-making factors regarding Australia international higher education. International Journal of Educational Management, 20(2), 91-100.

Cornuel, E. (2007). Challenges facing business schools in the future. Journal of Management Development, 26(1), 87-92.

Cubillo, J.M., Sanchez, J., \& Cervino, J. (2006). International students' decision-making process. International Journal of Educational Management, 20(2), 101-115.

DeShields Jr., O.W., Kara, A., \& Kaynak, E. (2005). Determinants of business student satisfaction and retention in higher education: Applying Herzberg's two-factor theory. International Journal of Educational Management, 19(2), 128-139.

Firdaus, Abdullah. (2006). Measuring service quality in higher education: HEdPERF verses SERVPERT. Marketing Intelligence \& Planning, 24(1), 31-47.

Habhajan, Singh. (2004). January 16, Private education at work, Focus on Education Section. Malaysian Business, 4-6.

Hair, J. F., \& Black, W. (1998). Multivariate Data Analysis, New Jersey: Prentice-Hall

Hanapi, Mohamad, Zahiruddin, Ghazali \& Mohd Shah, Kassim. (2003). The development of global education in Malaysia: Strategies for internationalization. Malaysian Management Review, 38(3), 75-85

Hemsley-Brown, J., \& Oplatka, I. (2006). Universities in a competitive global marketplace: A systematic review of the literature on higher education marketing. International Journal of Public Sector Management, 19(4), 316-338

Joseph, M., \& Joseph, B. (2000). Indonesian students' perceptions of choice criteria in the selection of a tertiary institutions: Strategic implications. International Journal of Educational Management, 14 (1), 40-44

Leblanc, G., \& Nyugen, N. (1997). Searching for excellence in business education: An exploratory study of customer impression of service quality. International Journal of Educational Management. 11(2). 72-79

Lenn, M. P. (2000). Higher education and the global marketplace: A practical guide to sustaining quality. On the Horizon, September/October, 7-10

Lindsay, A. (1994). Quality and management in universities. Journal of Tertiary Education Administration, 16(1), May, 55-68

Malaysian Education. (2005). Private education: The development \& progress of private education in Malaysia. 32-37

Malhotra, N. K. (1999). Marketing research. ( $3^{\text {rd }}$ ed.). New Jersey: Prentice Hall

Maringe, F. (2006). University and course choice: Implication for positioning, recruitment and marketing. International Journal of Educational Management, 20(6), 466-479

Maringe, F., \& Carter, S. (2007). International students' motivations for studying in UK HE: Insights into the choice and decision making of African students. International Journal of Educational Management, 21(6), 459-475

Mazzarol, T., \& Soutar, G. N. (2002). Push-pull factors influencing international student destination choice. International Journal of Educational Management, 16(2), 82-90 
Noran, Fauziah \& Ahmad, Mahdzan. (1997). Development of graduate education in Malaysia: Prospect for internationalization. Paper presented at the 2000 ASAIHL. Seminar on University and Society, 19-20 May 2000, Thailand

Navarro, M. M., Iglesias, M. P., \& Torres, P. R. (2006). A new management element for universities: Satisfaction with the offered courses. International Journal of Educational Management, 19(6), 505-526

Nunnally, J.C. (1978). Psychometric theory (2 ${ }^{\text {nd }}$ ed.). New York: McGraw-Hill

Parameswaran, R., \& Glowacka, A.E. (1995). University image: An information processing perspective. Journal of Marketing for Higher Education, 6(2), 41-56

Rohaizat, Baharun. (2004). Identifying needs and wants of university students in Malaysia. Malaysian Management Review. 39(2), 59-64

Ross, M., Heaney, J., \& Cooper, L. (2007). Institutional and managerial factors affecting international student recruitment management. International Journal of Educational Management, 21(7), 593-605

Soutar, N., \& Tuner, P.J. (2002). Students' preferences for university: A conjoint analysis. International Journal of Educational Management, 16(1), 40-45

Sunita, P., Pentecost, R., \& Ofstad, L. (2005). The influence of explicit and implicit service promises on Chinese students; expectations of overseas universities. Asia Pacific Journal of Marketing and Logistics, 18(2), 129-145

Tan, A. M. (2002). Malaysian private higher education: globalisation, privatisation, transformation and marketplaces. London: Asean Academic Press

Tang, T. L., Tang, D. S., \& Tang, C. S. (2004). College tuition and perceptions of private university quality. International Journal of Educational Management, 18(5), 304-316

Yamamoto, G. T. (2006). University evaluation-selection: A Turkish case. International Journal of Educational Management, 20(7), 559-569 
Table 1. Summary of studies on choice of criteria of study destination

\begin{tabular}{|c|c|c|}
\hline Author & Targeted population \& country & Summary \\
\hline $\begin{array}{l}\text { Leblanc \& Nguyen } \\
\text { (1999) }\end{array}$ & $\begin{array}{l}\text { Random sample of } 700 \text { students } \\
\text { from business school in Canada. }\end{array}$ & $\begin{array}{l}6 \text { factors - satisfaction value, epistemic } \\
\text { value, image, emotional value, price and } \\
\text { quality and social value. }\end{array}$ \\
\hline $\begin{array}{l}\text { Joseph \& Joseph } \\
(2000)\end{array}$ & $\begin{array}{l}\text { Random sample of } 200 \text { students } \\
\text { from Indonesia. }\end{array}$ & $\begin{array}{l}5 \text { factors- course \& career information, } \\
\text { facilities, cost of education, degree } \& \text { value } \\
\text { of education. }\end{array}$ \\
\hline $\begin{array}{l}\text { Soutar } \quad \& \quad \text { Turner } \\
(2002)\end{array}$ & $\begin{array}{l}\text { Western Australian school leavers } \\
\text { (the major group who enrolled at } \\
\text { state tertiary institutions). }\end{array}$ & $\begin{array}{l}4 \text { factors - course suitability, academic } \\
\text { reputation, job prospects and teaching } \\
\text { quality. }\end{array}$ \\
\hline $\begin{array}{l}\text { Hanapi, Zahiruddin \& } \\
\text { Mohd Shah (2003) }\end{array}$ & $\begin{array}{l}\text { International students in public \& } \\
\text { private institutions in Malaysia. }\end{array}$ & $\begin{array}{l}4 \text { factors - course characteristics, country } \\
\text { characteristics, administrative processes \& }\end{array}$ \\
\hline $\begin{array}{l}\text { Binsardi \& Ekwulugo } \\
(2003)\end{array}$ & $\begin{array}{l}\text { International } \text { students from } \\
\text { developed and developing } \\
\text { countries. }\end{array}$ & $\begin{array}{l}4 \text { factors - educational standard, university } \\
\text { admissions, employment, social factors } \\
5 \text { factors- reputation of education, }\end{array}$ \\
\hline Rohaizat (2004) & $\begin{array}{l}\text { Senior and junior students in four } \\
\text { Malaysian public universities. }\end{array}$ & $\begin{array}{l}\text { programme structure, conducive facilities } \\
\text { and resources, choice influencers and } \\
\text { customer orientation. }\end{array}$ \\
\hline $\begin{array}{l}\text { Navarro, Iglesias } \\
\text { Torres }(2006)\end{array}$ & $\begin{array}{l}\text { Students from five major } \\
\text { disciplines at Spanish Universities. }\end{array}$ & $\begin{array}{l}5 \text { factors }- \text { teaching methods, } \\
\text { administration, teaching staff, enrolment } \\
\text { and infrastructures. }\end{array}$ \\
\hline Firdaus (2006) & $\begin{array}{l}\text { Students from two public } \\
\text { universities, one private university } \\
\text { and three private colleges in } \\
\text { Malaysia. }\end{array}$ & $\begin{array}{l}4 \text { factors - non-academic aspects, academic } \\
\text { aspects, reliability and empathy. }\end{array}$ \\
\hline Maringe (2006) & $\begin{array}{l}\text { Students from schools and } \\
\text { Colleges in the Southampton } \\
\text { University Partnership scheme. }\end{array}$ & $\begin{array}{l}2 \text { key signals - employment and career } \\
\text { prospects and programme and price. }\end{array}$ \\
\hline $\begin{array}{l}\text { Maringe } \\
(2007)\end{array}$ & $\begin{array}{l}\text { African Students who choose to } \\
\text { study abroad and at UK. }\end{array}$ & $\begin{array}{lrr}7 \text { factors }- & \text { recognition, international } \\
\text { quality, safe, part-time jobs, learning } \\
\text { environments, } & \text { opportunities } \\
\text { post-graduate, easy application process. }\end{array}$ \\
\hline
\end{tabular}

Source: compiled from the literature

Table 2. Mean value of choice criteria

\begin{tabular}{|l|c|l|c|}
\hline Most Important Items & Importance & Least important items & Importance \\
\hline Entry qualification & 4.98 & Education expo & 4.20 \\
English usage & 4.94 & Exchange rate & 4.19 \\
English language & 4.94 & Sports recreation & 4.17 \\
Specialized field & 4.83 & Internet & 4.11 \\
Academic staff & 4.83 & Friends from same country & 4.04 \\
Clean facilities & 4.81 & Printed media & 4.00 \\
Career advisor & 4.81 & Electronic media & 3.99 \\
Visa & 4.72 & Beautiful & 3.81 \\
Religion & 4.71 & Relatives & 3.75 \\
Internet facilities & 4.68 & Outskirts of the city & 2.93 \\
\hline
\end{tabular}

Note: 1 - extremely unimportant to 6 - extremely important. 
Table 3. Factor analysis of choice criteria of study destination

\begin{tabular}{|c|c|c|c|c|c|c|c|}
\hline & Factor 1 & Factor 2 & Factor 3 & Factor 4 & Factor 5 & Factor 6 & Factor 7 \\
\hline $\begin{array}{l}\text { Quality learning environment } \\
\text { Qualification } \\
\text { Staff } \\
\text { English usage } \\
\text { University reputation } \\
\text { Courses offered } \\
\text { Course duration } \\
\text { Specialized field } \\
\text { Visa } \\
\text { Political stability } \\
\text { Entry requirement } \\
\text { G2G collaboration }\end{array}$ & $\begin{array}{l}0.69 \\
0.69 \\
0.68 \\
0.66 \\
0.62 \\
0.62 \\
0.61 \\
0.61 \\
0.60 \\
0.56 \\
0.56\end{array}$ & & & & & & \\
\hline $\begin{array}{l}\text { Decision influencers } \\
\text { Relatives } \\
\text { Printed media } \\
\text { Electronic media } \\
\text { Education expo } \\
\text { Internet } \\
\text { Friends } \\
\text { Education agent } \\
\text { Parents } \\
\text { Responsiveness of university }\end{array}$ & & $\begin{array}{l}0.72 \\
0.71 \\
0.71 \\
0.68 \\
0.68 \\
0.66 \\
0.62 \\
0.60 \\
0.51\end{array}$ & & & & & \\
\hline $\begin{array}{l}\text { Customer focus } \\
\text { Regulations } \\
\text { Community accepted } \\
\text { Culture } \\
\text { Campus life } \\
\text { Religion } \\
\text { Carrier advisor } \\
\text { International students' advisor } \\
\text { English language }\end{array}$ & & & $\begin{array}{l}0.66 \\
0.64 \\
0.62 \\
0.62 \\
0.59 \\
0.59 \\
0.54 \\
0.53\end{array}$ & & & & \\
\hline $\begin{array}{l}\text { Cost of education } \\
\text { Cost } \\
\text { Funding } \\
\text { Exchange rate } \\
\text { Accommodation }\end{array}$ & & & & $\begin{array}{l}0.72 \\
0.84 \\
0.57 \\
0.54\end{array}$ & & & \\
\hline $\begin{array}{l}\text { Facilities } \\
\text { Design/layout } \\
\text { Clean } \\
\text { Sport recreation } \\
\text { Internet facilities }\end{array}$ & & & & & $\begin{array}{l}0.73 \\
0.63 \\
0.52 \\
0.51\end{array}$ & & \\
\hline $\begin{array}{l}\text { Socialization } \\
\text { Urban area } \\
\text { Part-time jobs }\end{array}$ & & & & & & $\begin{array}{l}0.65 \\
0.51\end{array}$ & \\
\hline $\begin{array}{l}\text { Location } \\
\text { Outskirts } \\
\text { Beautiful }\end{array}$ & & & & & & & $\begin{array}{l}0.63 \\
0.56\end{array}$ \\
\hline $\begin{array}{l}\text { Eigenvalue } \\
\text { Cumulative of variance } \\
\text { explained Cronbach's alpha }\end{array}$ & $\begin{array}{l}17.64 \\
36.74 \\
0.913\end{array}$ & $\begin{array}{l}3.02 \\
43.04 \\
0.90\end{array}$ & $\begin{array}{l}2.12 \\
47.45 \\
0.90\end{array}$ & $\begin{array}{l}1.32 \\
50.19 \\
0.74\end{array}$ & $\begin{array}{l}1.24 \\
52.77 \\
0.78\end{array}$ & $\begin{array}{l}1.12 \\
55.09 \\
0.52\end{array}$ & $\begin{array}{l}1.08 \\
57.09 \\
0.30\end{array}$ \\
\hline
\end{tabular}


Table 4. Differences in factors of choice criteria by region

\begin{tabular}{|l|c|c|c|c|}
\hline \multicolumn{1}{|c|}{ Factors } & Africa & The rest of Asia & Middle East & Southeast Asia \\
\hline Quality learning environment & $3.44^{* *}$ & 3.26 & $3.40^{* *}$ & 3.22 \\
Decision influencers & 3.03 & 2.81 & $3.21^{*}$ & 2.76 \\
Customer focus & $3.20^{* *}$ & $3.12^{*}$ & $3.23^{* *}$ & $3.22^{*}$ \\
Cost of education & 3.10 & 2.91 & 2.93 & $3.32^{*}$ \\
Facilities & $3.29^{*}$ & $3.21^{*}$ & 2.95 & 3.02 \\
Socialization & 3.20 & 3.05 & 3.21 & $3.33^{*}$ \\
Location & $3.32^{*}$ & 2.98 & 3.11 & 3.07 \\
F & 2.985 & 2.275 & 2.762 & 2.221 \\
p-value & 0.085 & 0.132 & 0.097 & 0.137 \\
\hline
\end{tabular}

Note: $* *$ Significant level at $0.01, *$ Significant level at 0.05 